\title{
Carboxypeptidase E (Enkephalin Convertase): mRNA Distribution in Rat Brain by in situ Hybridization
}

\author{
Mathew W. MacCumber, ${ }^{1,4}$ Solomon H. Snyder, ${ }^{1,2,3}$ and Christopher A. Ross ${ }^{1,2}$ \\ Departments of ${ }^{N}$ Neuroscience, ${ }^{2} P$ sychiatry and Behavioral Sciences, ${ }^{3}$ Pharmacology and Molecular Sciences, and \\ ${ }^{4}$ Ophthalmology, Johns Hopkins University School of Medicine, Baltimore, Maryland 21205
}

\begin{abstract}
Carboxypeptidase E (CPE), also referred to as enkephalin convertase or carboxypeptidase $\mathrm{H}$ (EC 3.4.17.10), is present in neurotransmitter secretory granules and can remove C-terminal basic residues following endopeptidase cleavage during peptide processing. Using in situ hybridization with ${ }^{35} \mathrm{~S}$-labeled oligonucleotide probes, we have mapped the localization of CPE mRNA in the rat brain. Specificity for CPE was confirmed by control experiments, which included production of identical patterns hybridization with 3 different antisense oligonucleotide probes, loss of label with
\end{abstract} RNase pretreatment of sections or co-incubation with excess unlabeled probe, and lack of labeling with sense orientation probes. In addition, the regional distribution of CPE mRNA by Northern blot analysis corresponded with distribution of labeling by in situ hybridization. The highest levels of CPE mRNA were found to be present in the pyramidal cells of the hippocampus, the pituitary anterior and intermediate lobes, the ependymal cells of the lateral ventricle, the endopiriform nucleus, the basolateral amygdala, the supraoptic nucleus, and the paraventricular nucleus. Intermediate levels were present in the thalamus, medial geniculate nucleus, lateral septal nucleus, piriform and entorhinal cortex, nucleus of the tractus solitarius, cerebellar cortex, pontine nuclei, and inferior olive. The lowest levels were found in the hippocampal granule cell layer, lateral hypothalamus, globus pallidus, and brain stem reticular formation. Ibotenic acid lesions of the hippocampus eliminated the majority of the label, which had been present over pyramidal cells, though labeling was increased over areas of reactive gliosis, suggesting that activated astrocytes can also synthesize CPE mRNA. In general, the localization of CPE mRNA in the rat brain corresponded to the distribution of enkephalin and other peptide neurotransmitter-synthesizing neurons, though CPE mRNA was also present in neurons that do not secrete known peptides and in reactive glia. The widespread yet specific localization of CPE mRNA in

Received Oct. 23, 1989; revised Apr. 16, 1990; accepted Apr. 17, 1990.

We wish to thank Lloyd D. Fricker for supplying the rat carboxypeptidase $E$ cDNA sequence prior to publication, Audrey Bentley for excellent technical assistance, and Nancy Bruce and Jackie Shaw for manuscript preparation. This work was supported by USPHS Grant DA-00266, a gift from the Bristol Myers Company, Research Scientist Award DA-00074 to S.II.S., Fellowship EY07047 to M.W.M., and Fellowship MH-43040 to C.A.R.

Correspondence should be addressed to Christopher A. Ross, M.D., Ph.D., Departments of Neuroscience and Psychiatry, The Johns Hopkins University School of Medicine, 725 N. Wolfe Street, Baltimore, Maryland 21205.

Copyright (C) 1990 Society for Neuroscience $0270-6474 / 90 / 082850-11 \$ 03.00 / 0$ the rat brain suggests it may be an excellent marker for peptide synthesizing cells in the CNS.

Biologically active peptides, including neurotransmitters and hormones, are often synthesized from precursor proteins with the active peptide flanked by dibasic amino acids. The sequential actions of an endopeptidase followed by a carboxypeptidase B-like cnzyme relcase the active peptide from the precursor. To understand the disposition of neurotransmitter peptides, it would be desirable to identify selective enzymes involved in their processing. Carboxypeptidase $\mathrm{E}$ (CPE), also referred to as enkephalin convertase or carboxypeptidase H (EC 3.4.17.10), is a carboxypeptidase B-like enzyme first identified and isolated from the brain and pituitary and adrenal glands (Fricker and Snyder, 1982; Supattapone et al., 1984; Fricker, 1988). The enzyme has an optimum $\mathrm{pH}$ of 5.5 , corresponding to the $\mathrm{pH}$ within neurotransmitter-storing granules, and occurs in both membranebound and soluble forms. CPE has been microscopically localized by immunohistochemistry (Hook et al., 1985; Lynch et al., 1989) and by autoradiography utilizing an extremely potent and selective inhibitor of the enzyme, ${ }^{3} \mathrm{H}$-guanidinoethylmercaptosuccinic acid ( ${ }^{3} \mathrm{H}$-GEMSA). The highest densities of the enzyme throughout the body occur in endocrine organs, such as the adrenal medulla, anterior and intermediate lobes of the pituitary gland (Strittmatter et al., 1985), areas of the heart that secrete atrial natriuretic factor (Lynch et al., 1988), and islet cells of the pancreas (Lynch et al., 1987). Within the brain, CPE protein is enriched in areas containing enkephalins, as well as in areas that synthesize other neuropeptides (Lynch et al., 1984, 1986, 1989; Hook et al., 1985; Lynch and Snyder, 1986). Some areas of the brain that do not synthesize known neuropeptides also appear to contain high densities of CPE protein (Lynch et al., 1986, 1989). Because CPE protein is contained in neuronal processes as well as neuronal cell bodies, it may be difficult to identify the cells that synthesize CPE with these techniques. Recently, molecular cloning of bovine and rat CPE has been carried out (Fricker et al., 1986, 1989). Utilizing the technique of $i n$ situ hybridization with radiolabeled oligonucleotide probes complementary to the mRNA of rat CPE, we have described the localization of $m R N \Lambda$ for CPE throughout the rat brain.

\section{Materials and Methods}

Rats (175-250 gm, male Sprague-Dawley) were sacrificed by decapitation. For some experiments, the rats were first deeply anesthetized with pentobarbital, then $20 \mu \mathrm{g}$ ibotenic acid in $1 \mu 10.1 \mathrm{~N} \mathrm{NaOH}$ was injected stereotaxically into the left hippocampus, and the animals were sacrificed 1 or $7 \mathrm{~d}$ later. The brains were rapidly removed, embedded in brain paste, and frozen on dry ice. Sections (12- $\mu \mathrm{m}$ thick) were cut in a cryostat onto slides coated with gelatin/chrome alum or poly-Llysine, then stored at $-70^{\circ} \mathrm{C}$. In situ hybridization was done by methods 
previously described (Davis et al., 1986; Young et al., 1986b; Largent et al., 1988; Ross et al., 1989), with minor modifications. Solutions were made with deionized distilled water treated with $0.1 \%$ diethylpyrocarbamate, then autoclaved. Sections were fixed in $4 \%$ freshly depolymerized paraformaldehyde in phosphate-buffered saline (PBS) for $5 \mathrm{~min}$, then rinsed twice in PBS. At this point, some control sections were incubated with RNase $A(0.2 \mathrm{mg} / \mathrm{ml}$ in PBS $)$ for $60 \mathrm{~min}$ at $37^{\circ} \mathrm{C}$, then washed twice with PBS. All sections were acetylated with $0.25 \%$ acetic anhydride: $0.1 \%$ triethanolamine in $0.9 \% \mathrm{NaCl}(\mathrm{pH}, 8.0)$ for $10 \mathrm{~min}$. Sections were then delipidated in chloroform for 5-10 min (preceded and followed by a graduated series of ethanols) and dried.

Oligonuclcotide probes were synthesized on an Applied Biosystems Model 380B or a MilliGene/Biosearch Model 7500 DNA synthesizer and purified by HPLC. Three 45-base-long sequences from the rat CPE mRNA sequence (Fricker et al., 1989) were chosen to avoid regions with known homology to other mRNAs and regions with greater than expected homology to rat structural RNA. Sense orientation sequence for each probe was as follows: 5'-TGGCTGCAGTGCACCGCCATCAGCAGGATCTACACGGTGGGGCGC-3' (bases 260-304), 5'-AATGAGGCGGTTGCACGGGGAGCTGCTCATTTTCTTGGCCCAGTAC-3' (bases 407-451), and 5'-GCATCTCAGCCCGGTGAGCTGAAGGACTGGTTCGTGGGCCGCAGC-3' (bases 557-601). For each sequence, a complementary (antisense) and identical (sense) orientation probe was synthesized. Probes were $3^{\prime}$-end-labeled with terminal transferase (50-70 units) (Bethesda Research Laboratories, Bethesda, MD) and dATP $\alpha^{-35} \mathrm{~S},(1200 \mathrm{Ci} / \mathrm{mmol}$; NEN/DuPont, Boston, MA) to a specific activity of $9600 \mathrm{Ci} / \mathrm{mmol}$ and separated from unincorporated nucleotides by column chromatography (NENSORB 20 column, NEN/DuPont). For labeling reactions, probes were labeled separately or equal amounts of the 3 antisense or 3 sense probes were mixed together ( $10 \mathrm{pmol}$ probes with $100 \mathrm{pmol}$ dATP). Probes were suspended in a hybridization buffer of $4 \times$ SSC: $1 \times$ Denhardt's solution: $1 \mathrm{~mm}$ EDTA:20 mM phosphate buffer, $\mathrm{pH}$ 7.4:0.1\% denatured salmon sperm DNA: $0.1 \%$ yeast tRNA: $10 \%$ dextran sulfate: $50 \%$ deionized formamide (Bethesda Research Laboratories, Bethesda, MD) $(1 \times$ SSC, $0.15 \mathrm{~m}$ $\mathrm{NaCl}: 0.015$ M sodium citrate; $1 \times$ Denhardt's solution, $0.02 \%$ bovine serum albumin:0.02\% Ficoll:0.02\% polyvinylpyrrolidone), and $10^{6} \mathrm{cpm}$ of probe in $100 \mu \mathrm{l}$ was applied per section. The hybridization buffer over the sections was covered with paraffin film, and the sections were incubated overnight in a humid atmosphere at $37^{\circ} \mathrm{C}$. In some control experiments, this incubation was carried out in the presence of 100-fold excess unlabeled probe. The next day, sections were washed in 3 changes of $1 \times \mathrm{SSC}$ at $55^{\circ} \mathrm{C}$ for a total of $1 \mathrm{hr}$. In melt curve experiments, sections were washed in $1 \times \mathrm{SSC}$ at $35^{\circ} \mathrm{C}$ or $45^{\circ} \mathrm{C}$ or $1 \times \mathrm{SSC}$ at $55^{\circ} \mathrm{C}$ plus various amounts of formamide: $15 \%$ (approximating a wash temperature of $65^{\circ} \mathrm{C}$ ), $30 \%$ (approximating $75^{\circ} \mathrm{C}$ ), $45 \%$ (approximating $85^{\circ} \mathrm{C}$ ), or $60 \%$ (approximating $95^{\circ} \mathrm{C}$ ). Sections were washed for a further 30 $\min$ in $1 \times$ SSC at room temperature, dipped once in cold water to rinse off salt, and dried under a stream of cool air. Sections were apposed to beta-sensitive film (Amersham Betamax) for 5-15 d and developed in D19. Some sections were dipped in Kodak NTB2 emulsion diluted $1: 1$ in water, exposed for 3-6 weeks, and developed in D19.

For Northern blots, probes were labeled with $\alpha{ }^{-32} \mathrm{P}-\mathrm{dATP}(5000 \mathrm{Ci} /$ $\mathrm{mmol}$ ), using terminal transferase, to a specific activity of $4 \times 10^{4} \mathrm{Ci}$ / mmol. RNA was purified by acid guanidinium/phenol/chloroform extraction (Chomczynski and Sacchi, 1987), fractionated on a $1 \%$ agarose gel with $0.66 \mathrm{M}$ formaldehyde as denaturant (Davis et al., 1986), and transferred to nylon membranes (Nytran, $0.45 \mu \mathrm{m}$; Schleicher and Schuell, Keene, $\mathrm{NH}$ ). Membranes were incubated with the labeled probe at $37^{\circ} \mathrm{C}$ overnight in hybridization buffer $(4 \times \mathrm{SSC}: 5 \times$ Denhardt's solution: $0.1 \%$ sodium dodecyl sulfate: $100 \mu \mathrm{g} / \mathrm{ml}$ salmon sperm DNA: $50 \%$ deionized formamide). Wash conditions were identical to those used for in situ experiments. Membranes were allowed to dry, then exposed to betasensitive film for 3-5 d. CPE mRNA levels were subsequently standardized to the amount of RNA loaded after membranes were rehybridized to a ${ }^{32} \mathrm{P}$-labeled oligonucleotide probe specific for $18 \mathrm{~S}$ ribosomal RNA.

Autoradiograms from some in silu hybridization experiments and Northern blots were quantified using an image analysis system (RAS R 1000; Amersham, Arlington Heights, IL). For autoradiograms of slides labeled by in situ hybridization, all 15 images of coronal brain slices from the same experiment were analyzed. Selected brain regions were outlined and quantified for optical density divided by area, then standardized to the optical density of the hippocampal pyramidal cell layer. Optical densities of white matter from several sections were the same
Table 1. Regional distribution of CPE mRNA in the rat brain

\begin{tabular}{ll} 
Brain region & $\begin{array}{l}\text { Relative optical } \\
\text { density }\end{array}$ \\
\hline Hippocampus & 1.00 \\
Frontal cortex & 0.63 \\
Striatum & 0.59 \\
Thalamus & 0.56 \\
Amygdala & 0.49 \\
Pyriform cortex & 0.46 \\
Basal forebrain & 0.45 \\
Cerebellum & 0.43 \\
Hypothalamus & 0.35 \\
Pons & 0.33 \\
Medulla & 0.29 \\
Olfactory bulb & 0.13
\end{tabular}

Data are based on the relative optical density of CPE mRNA from Northern blot analyss (Fig. 1). CPE mRNA levels were standardized to the amount of RNA determined after membranes were rehybridized with an $18 \mathrm{~S}$ ribosomal RNAspecific oligonucleotide probe.

(within 10\%), showing insignificant variability in exposure and section thickness.

\section{Results}

Northern blot analysis of CPE $m R N A$. To establish that the oligonucleotide probes used in this study interact only with mRNA for CPE, we conducted Northern blot analyses of numerous brain regions (Fig. 1). In all areas of the brain, 1 single oligonucleotide probe or the mixture of 3 oligonucleotides labeled a single band of about 2.3 kilobases. The density of the band varied in different brain regions, with the greatest density in the hippocampus and the lowest density in the olfactory bulb (Table 1). Only negligible cross-hybridization with $18 \mathrm{~S}$ and $28 \mathrm{~S}$ ribosomal RNA was present.

General properties of in situ hybridization for CPE. For in situ hybridization experiments, 3 separate probes from different parts of the cDNA sequence for CPE were employed. Patterns of localization were identical with each of the 3 probes. Discrete localizations were observed for CPE mRNA, with a particularly dense band of radiolabeling in the hippocampus, corresponding to the highest density of CPE mRNA determined by Northern blot analysis (Fig. 2). A similarly prominent localization was observed in the ependymal layer of the anterior horn of the lateral ventricles. To ensure that labeling of the sections was specific to CPE mRNA, we conducted several control experiments. No detectable hybridization was observed with sense orientation probes radiolabeled to the same specific activity (Fig. 2). Negligible antisense labeling was observed in sections pretreated with RNase or co-incubated with 100-fold excess of unlabeled antisense probe (data not shown). As a further control, we examined in situ hybridization at increasing temperatures. The melt temperature $\left(\mathrm{T}_{\mathrm{m}}\right)$ was at approximately $72^{\circ} \mathrm{C}$, with a sharp transition corresponding to the expected $\mathrm{T}_{m}$ for oligonucleotide probes with the G-C content of those employed (data not shown). For all tissues examined, including pituitary and adrenal, appropriate controls, including the use of a labeled sense probe and 100-fold excess unlabeled antisense probe, gave results similar to those with adult brain tissue.

$C P E m R N A$ in pituitary and adrenal tissues. CPE mRNA was most concentrated in the intermediate lobe of the pituitary gland, with somewhat less labeling in the anterior lobe (Fig. 3). No 


\section{OB FC PC St Hi Bf AmTh Hy Cb Po Me}

285

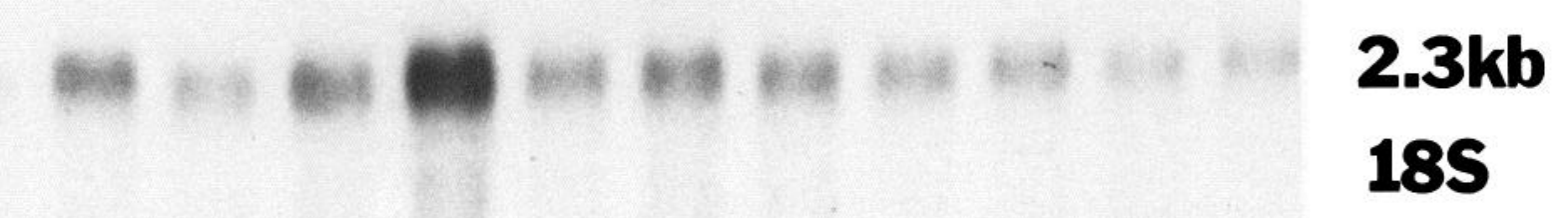

Figure 1. Northern blot analysis of CPE mRNA levels in different brain regions. OB, olfactory bulb; FC, frontal cortex; PC, piriform cortex; St, striatum; Hi, hippocampus; $\mathrm{BF}$, basal forebrain; Am, amygdala; Th, thalamus; $\mathrm{Hy}$, hypothalamus; $\mathrm{Cb}$, cerebellum; $\mathrm{Po}$, pons; Me, medulla.

labeling was observed in the posterior lobe. In the adrenal tissues, CPE mRNA was moderately concentrated in the medulla, with negligible levels in the cortex (Fig. 3).

Effect of dehydration on CPE $m R N A$ levels. Strittmatter et al. (1985) demonstrated that dehydration depletes CPE protein in the posterior pituitary by greater than $75 \%$. We used Northern blot and in situ hybridization analyses to test whether similar treatment affects CPE mRNA in the paraventricular and supraoptic nuclei. The level of CPE mRNA as measured by either technique was the same in 4 dehydrated rats as in 4 controls (data not shown).

Effect of ibotenic acid lesions on CPE $m R N A$. To ascertain whether brain CPE mRNA observed by in situ hybridization is contained in neurons or other cellular elements, we lesioned hippocampal neurons with an injection of ibotenic acid, and harvested the rat brains after 1 or $7 \mathrm{~d}$. Cresyl violet staining revealed a substantial loss of neurons at either day 1 or $\mathrm{d} 7$, with associated gliosis in the area of the ibotenic acid injection at day 7 (Fig. 4). In the unlesioned side, the radiolabel was most intense throughout the pyramidal cell layer of the hippocampus, with much lower densities in the dentate gyrus. Labeling was virtually abolished from both the hippocampal pyramidal cells and the dentate gyrus granule cells by ibotenic acid treatment at either day 1 (not shown) or day 7 postinjection (Fig. 4). However, at $7 \mathrm{~d}$ moderate labeling was present on the treated side, apparently in association with reactive glia (Fig. 4; see Discussion).
Mapping of CPE $m R N A$ throughout the rat brain. To explore the detailed localization of CPE mRNA, we conducted in situ hybridization in sagittal sections (Fig. 2) and at numerous coronal levels of the rat brain (Figs. 5-7). Relative values for selected brain regions were quantitated by image analysis (Table 2).

In the olfactory bulb, fairly intense labeling was observed in discrete layers (Fig. 6), which were sufficiently narrow that overall labeling of the olfactory bulb in Northern blots was not pronounced (Fig. 1). The densest labeling occurred over the mitral cells, the major output cells of the olfactory bulb. Moderate labeling was observed over the periglomerular cells, which are interneurons of the glomerular layer. Moderate to dense labeling was also present over tufted cells. By contrast, little or no labeling was observed over any of the cell types of the granule cell layer. Moderate labeling was observed over the anterior olfactory nuclei (Fig. $5 A$ ).

Moderate labeling was observed over most layers of the cerebral cortex, with frontal and parietal areas more densely labeled than the occipital cortex, but the densest labeling was observed over the piriform cortex (Fig. $5 B$ ). Moderate labeling was present over the entorhinal cortex (Fig. $5 J$ ), and intense labeling was observed in the claustrum and the endopiriform nucleus (Fig. $5 C$ ).

A dense band of labeling was observed over the ependymal layer lining the lateral ventricles (Fig. 6). The inferior horn was more densely labeled than the anterior horn, while the epen- 

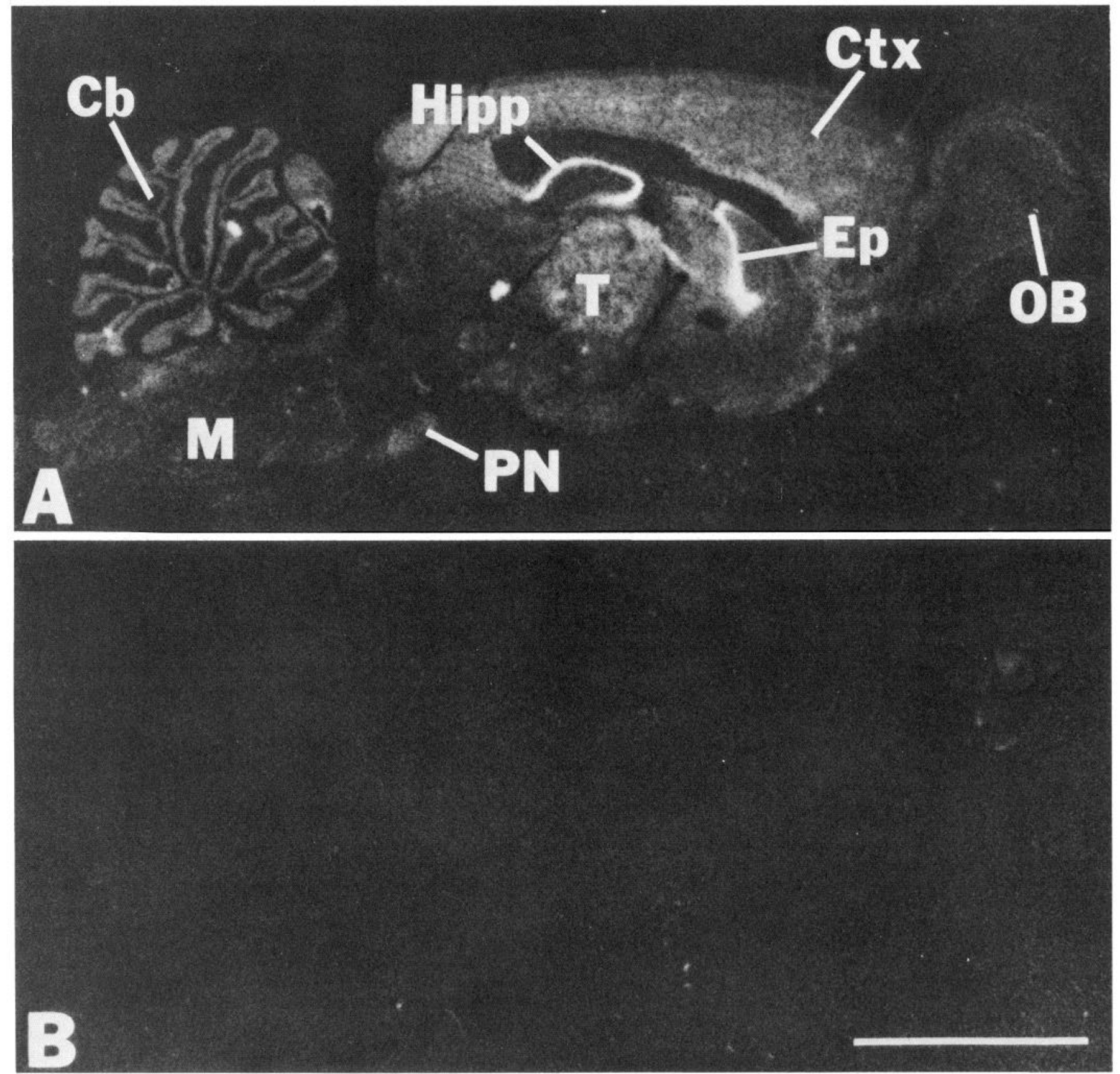

Figure 2. CPE antisense probe hybridization to adult rat sagittal brain section with controls. $A$, Labeled antisense probe alone. $B$, Labeled sense probe. $\mathrm{Cb}$, cerebellum; $\mathrm{Ctx}$, cerebral cortex; Ep, ependyma; Hipp, hippocampus; M, medulla; OB, olfactory bulb; PN, pontine nucleus. Scale bar, 5 $\mathrm{mm}$.

Figure 3. CPE antisense probe hybridization to adult rat pituitary and adrenal gland sections. AC, adrenal cortex; $\mathrm{AL}$, anterior lobe of pituitary; $\mathrm{AM}$, adrenal medulla; IL, intermediate lobe of pituitary; PL, posterior lobe of pituitary. Scale bar, $2 \mathrm{~mm}$.

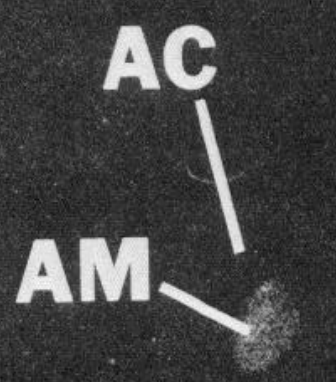

2.

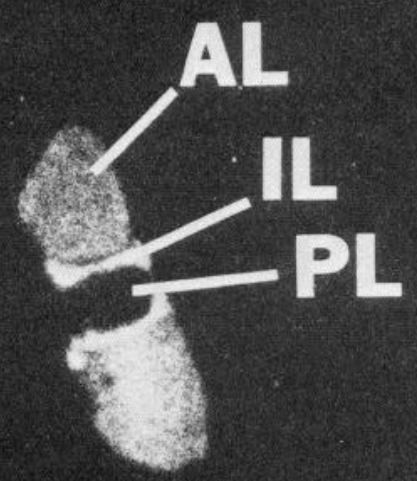




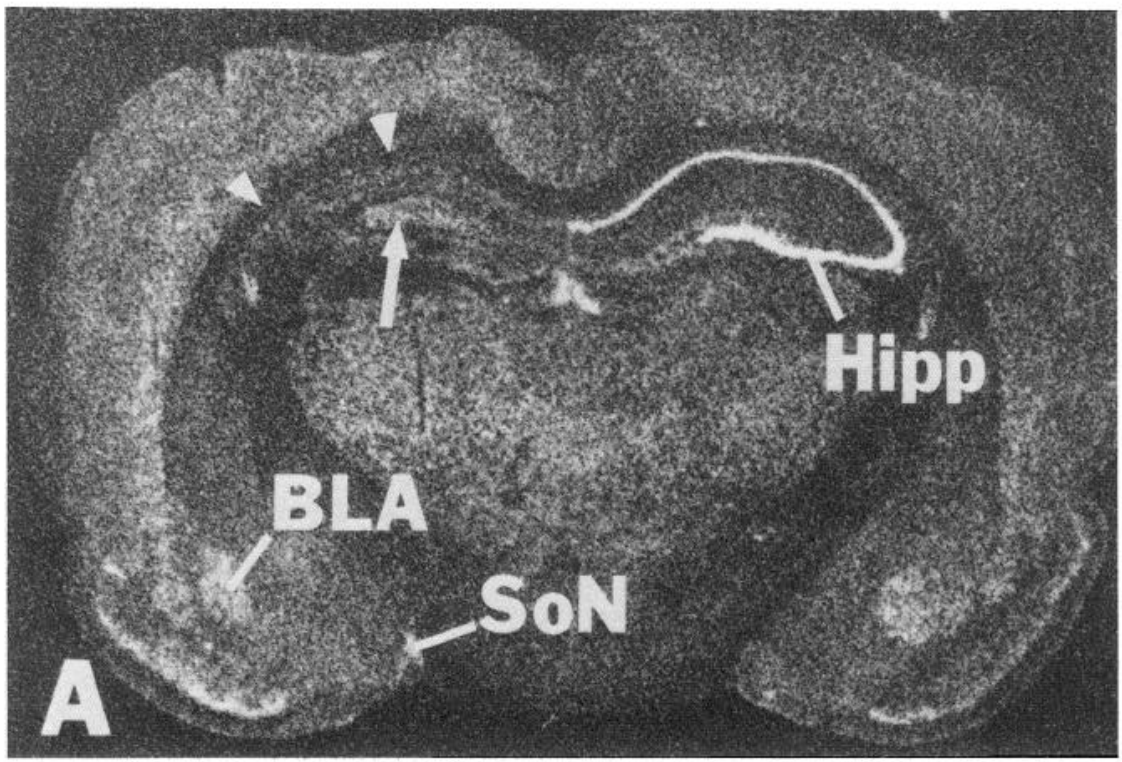

Figure 4. CPE antisense probe hybridization to adult rat brain coronal section $7 \mathrm{~d}$ after hippocampal neurons were destroyed by injection of ibotenic acid (as described in Materials and Methods). $A, \mathrm{CPE}$ antisense probed hybridization. $B$, Adjacent section stained with Cresyl violet to show the selective loss of hippocampal neurons. Arrowheads indicate neuronal loss in area CA1, with loss of label. Arrows indicate area of reactive gliosis, with increased label. BLA, basolateral amygdala; Hipp, hippocampus; SoN, supraoptic nucleus. Scale bar, $5 \mathrm{~mm}$.

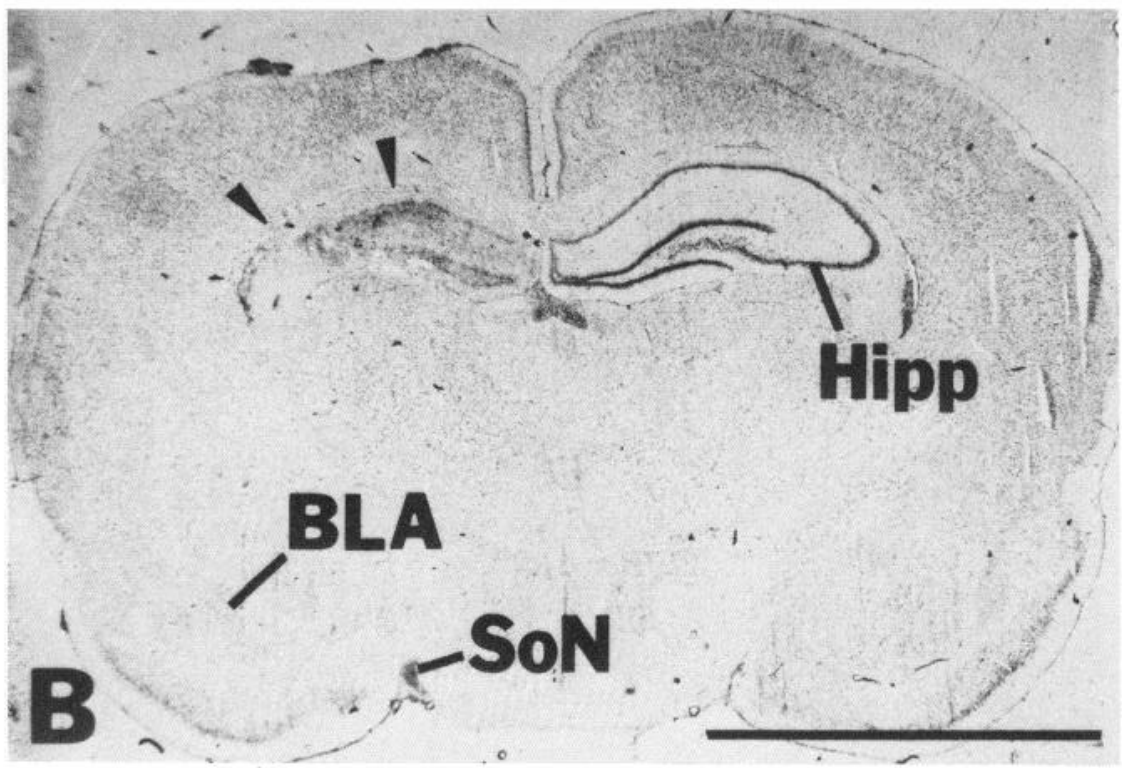

dymal cells of the olfactory bulb were unlabeled. The ependymal cells of the third ventricle, cerebral aqueduct, and fourth ventricle were also unlabeled.

In the basal forebrain, labeling was densest in the lateral septum (Fig. 5C) and notably lighter in the medial septum. Labeling was also dense in the bed nucleus of the stria terminalis (Fig. $5 C$ ). The nucleus of the diagonal band contained a moderate amount of CPE mRNA, while the olfactory tubercle was lighter, as were the Islands of Caleja. The subfornical organ (Fig. 5D) was moderately to densely labeled. CPE mRNA was moderate to dense in the preoptic area in its median, ventromedial, and medial subnuclei, but was relatively light in its lateral subnucleus (Fig. 5D).

In the basal ganglia, the caudate-putamen were lightly to moderately labeled, while in the nucleus accumbens, labeling was moderately dense (Fig. 5, $B-E$ ). By contrast, the globus pallidus and ventral pallidum were very lightly labeled (Fig. 5, $C, D$ ).

The hippocampus was among the areas of the brain that contained the highest levels of CPE mRNA (Fig. 5, $E-H$ ). Labeling was intense over pyramidal cells in layers CA1 through CA4 (Fig. 7), with the greatest density in CA3 and CA4. By contrast, labeling was markedly lower in the dentate gyrus, with only barely detectable labeling over the granule cells. However, neurons adjacent to the granule cell layer were labeled approximately as densely as the pyramidal cells (Fig. 7).

The basolateral and lateral nucleus of the amygdala contained a high level of CPE mRNA (Fig. 5, $C, F$ ), while other subnuclei of the amygdala, including the central nucleus, contained a light to moderate amount.

Labeling in many regions of thalamus was moderately dense (Fig. 5, $E-G$ ), including the ventrolateral nuclei, anterior nuclear complex, posterior nucleus, and medial geniculate nucleus. By contrast, the reticular nucleus and centromedian nucleus were much lighter. Labeling was intense in the medial habenula but light in the lateral habenula (Fig. $5 F$ ). The zona incerta was moderately labeled (Fig. 5, E, F). The medial geniculate nucleus and lateral geniculate nucleus were also moderately to densely labeled (Fig. $5 H$ ). 

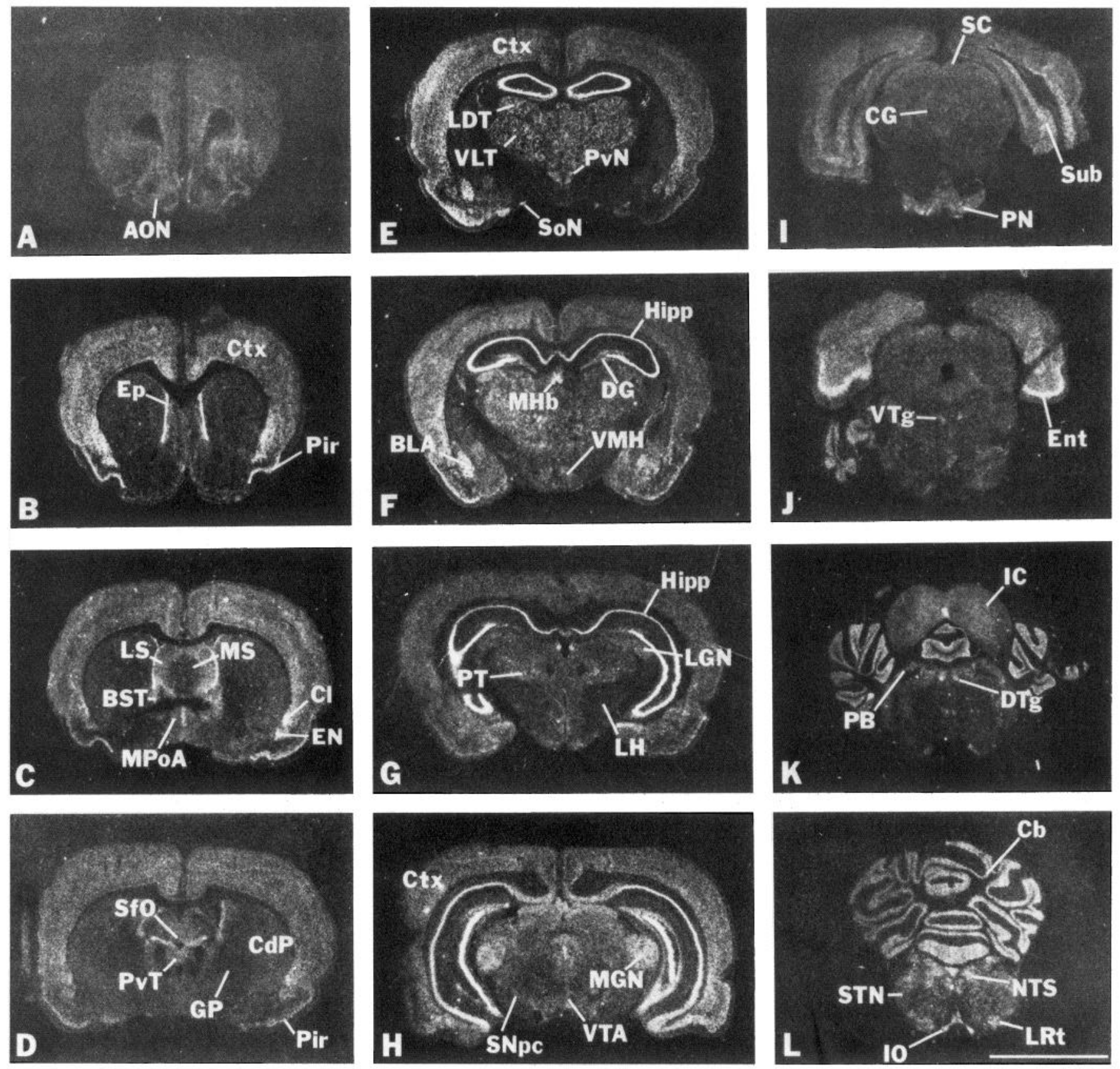

Figure 5. CPE antisense probe hybridization mapped in adult rat brain coronal sections. AON, anterior olfactory nucleus; BLA, basolateral amygdala; BST, bed nucleus of the stria terminalis; $\mathrm{Cb}$, cerebellum; CdP, caudate-putamen; CG, central gray; $\mathrm{Cl}$, claustrum; Ctx, cortex; DG, dentate gyrus; DTg, dorsal tegmental nucleus; EN, endopiriform nucleus; Ent, entorhinal cortex; Ep, ependyma; GP, globus pallidus; Hipp, hippocampus; IC, inferior colliculus; IO, inferior olive; LDT, lateral dorsal thalamus; LGN, lateral geniculate nucleus; LH, lateral hypothalamus; LRt, lateral reticular nucleus; LS, lateral septal nucleus; MGN, medial geniculate nucleus; MHb, medial habenula; MPoA, medial preoptic area; MS, medial septal nucleus; NTS, nucleus of the tractus solitarius; PB, parabrachial nucleus; Pir, piriform cortex; PN, pontine nucleus; PvN, paraventricular nucleus; PvT, paraventricular thalamic nucleus; PT, posterior thalamic nucleus; SC, superior colliculus; SNpc, substantia nigra pars compacta; SoN, supraoptic nucleus; SfO, subfornical organ; STN, spinal tract of trigeminal nucleus; Sub, subiculum; VLT, ventrolateral thalamic nucleus; VMH, ventral medial hypothalamus; VTA, ventral tegmental area; VTg, ventral tegmental nucleus. Scale bar, 5 mm.

The paraventricular nucleus and the supraoptic nucleus were densely labeled (Fig. $5 E$ ). Within the paraventricular nucleus, the magnocellular portion was more densely labeled than the parvocellular portion. Overall, the hypothalamus generally had lower levels of CPE than the thalamus. The ventromedial nuclei, the dorsomedial nuclei, and regions around the mammillary bodies were moderately labeled, while the lateral hypothalamus was lightly labeled.
In the midbrain, the inferior colliculus was more densely labeled than the superior colliculus (Fig. 5, $H-K$ ). The red nucleus, ventral tegmental area, central gray, and pars compacta of the substantia nigra were slightly less densely labeled. Lower levels of CPE mRNA were present in the pars reticulata of the substantia nigra, and markedly lower levels were present in the midbrain reticular formation.

Overall, the brain stem contained the lowest level of CPE 

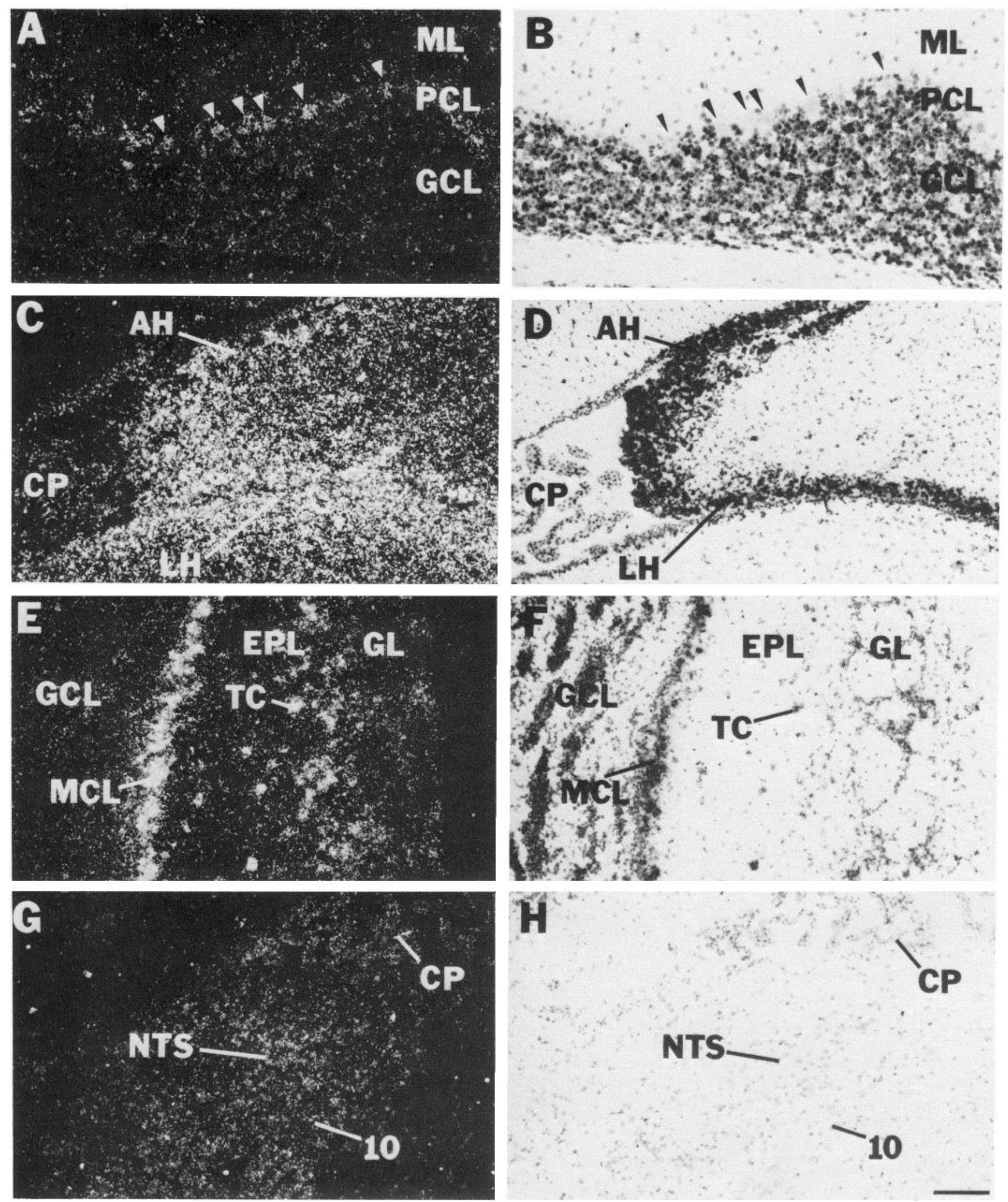

Figure 6. Photomicrographs of CPE antisense labeling of rat brain sections. $A$ and $B$, Cerebellum; arrowheads point to Purkinje cell bodies. $C$ and $D$, Ependymal cells lining lateral ventricles. $E$ and $F$, Olfactory bulb. $G$ and $H$, Nucleus of the tractus solitarius and dorsal vagal nucleus. GCL, granule cell layer; ML, molecular layer; PCL, Purkinje cell layer; $\mathrm{AH}$, anterior horn of lateral ventricle; $\mathrm{CP}$, choroid plexus; $\mathrm{LH}$, lateral horn of lateral ventricle; EPL, external plexiform layer; GL, glomerular layer; MCL, mitral cell layer; TC, tufted cell; CP, choroid plexus of fourth ventricle; NTS, nucleus of the tractus solitarius; 10 , dorsal vagal nucleus. Scale bar, $100 \mu \mathrm{m}$. 
mRNA (Fig. 5, $I-L$ ). However, the ventral tegmental nucleus, dorsal tegmental nucleus, pontine nuclei, parabrachial nucleus, and mesencephalic trigeminal nucleus were moderately to densely labeled. Other nuclei that were lightly to moderately labeled were the spinal trigeminal nucleus, the nucleus of the tractus solitarius (Fig. 6), and the inferior olive. The choroid plexus was also lightly to moderately labeled (Fig. 6). Lower levels of CPE mRNA were present in the cochlear nucleus, vestibular nuclei, nucleus cuneatus and gracilis, and locus coeruleus. Neurons of the brain stem reticular formation were overall very lightly labeled.

In the cerebellum, dense labeling occurred over the Purkinje cells (Figs. $5, K, L ; 6$ ). Granule cells, being very closely packed, appeared moderately labeled on the film autoradiogram (Fig. 5; $K, L$ ), but emulsion-dipped slides showed them to be considerably less densely labeled than Purkinje cells (Fig. 6). Deep cerebellar nuclei were lightly labeled.

No labeling above background was observed in white matter, meninges, or blood vessels in any part of the brain.

\section{Discussion}

The major findings of the present study were the discrete localizations of high levels of CPE mRNA in specific locations in brain and the widespread expression of CPE mRNA at lower levels in many brain areas. The localizations we found by in situ hybridization were specific, as shown by the lack of labeling in a number of control experiments, including co-incubation of labeled antisense probe with excess unlabeled antisense probe, pretreatment of tissue sections with RNase, washing of sections above appropriate melt temperatures, and incubation of tissue sections with sense orientation probe labeled to the same specific activity as the antisense probe. Furthermore, 3 antisense probes complementary to different regions of the CPE message all yielded apparently identical autoradiographs. Finally, the distribution of laheling with in situ hybridization closely corresponded to regional differences in the amount of CPE expression by Northern blot analysis.

Most of the CPE mRNA labeling was clearly over neuronal profiles, suggesting that the predominant expression of $\mathrm{CPE}$ mRNA is neuronal. However, the increase in labeling in the hippocampus after ibotenic acid lesioning of neurons suggests that reactive glia also can synthesize moderate levels of CPE mRNA. Vilijn et al. (1989) have recently demonstrated that cultured astrocytes can synthesize and secrete CPE. Cultured astrocytes from various brain regions can express peptide genes, including proenkephalin (Vilijn et al., 1988), somatostatin (Shinoda et al., 1989) and angiotensinogen (Stornetta et al., 1988). Therefore, CPE may process neuropeptides in both neurons and glia.

In most cases, the distribution of CPE mRNA expression in the brain agrees well with the distribution of CPE protein as studied using immunocytochemistry or GEMSA autoradiography (Lynch et al., 1984, 1986, 1989; Hook et al., 1985). By both in situ hybridization and GEMSA autoradiography, levels are high in the lateral septum, nucleus of the stria terminalis, piriform cortex, and medial habenula (Lynch et al., 1984, 1986). We found a high level of CPE mRNA expression in ependymal cells lining the lateral ventricle, similar to that found by Lynch et al. (1984; their Fig. 1). CPE protein and mRNA are both concentrated in hippocampal pyramidal layers, with higher levels in areas CA 3 and CA4 than CA1 and CA2, while levels in the dentate gyrus granule cells are considerably lower, if present at
Table 2. Distribution of CPE mRNA in selected areas of the rat brain

\begin{tabular}{|c|c|}
\hline Brain area & $\begin{array}{l}\text { Relative } \\
\text { optical } \\
\text { density }\end{array}$ \\
\hline Hippocampus, pyramidal cell layer & 1.00 \\
\hline Piluilary, intermediate lobe & 0.87 \\
\hline Pituitary, anterior lobe & 0.73 \\
\hline Dorsal tegmental nucleus & 0.68 \\
\hline Endopiriform nucleus & 0.56 \\
\hline Ependyma, lateral ventricles & 0.56 \\
\hline Inferior colliculus & 0.55 \\
\hline Amygdala, basolateral nucleus & 0.54 \\
\hline Claustrum & 0.53 \\
\hline Thalamus, lateral dorsal nucleus & 0.51 \\
\hline Paraventricular nucleus & 0.47 \\
\hline Supraoptic nucleus & 0.47 \\
\hline Parabrachial nucleus & 0.46 \\
\hline Anterior olfactory nucleus & 0.45 \\
\hline Thalamus, ventrolateral nucleus & 0.44 \\
\hline Bed nucleus of stria terminalis & 0.42 \\
\hline Subiculum & 0.42 \\
\hline Amygdala, central nucleus & 0.41 \\
\hline Cortex, piriform & 0.41 \\
\hline Lateral septal nucleus & 0.41 \\
\hline Cortex, entorhinal & 0.40 \\
\hline Nucleus of the tractus solitarius & 0.40 \\
\hline Medial habenula & 0.38 \\
\hline Cerebellum, granule cell layer & 0.37 \\
\hline Cortex, frontal & 0.36 \\
\hline Pontine nucleus & 0.36 \\
\hline Hippocampus, dentate gyrus & 0.33 \\
\hline Ventral tegmental nucleus & 0.33 \\
\hline Caudate-putamen & 0.32 \\
\hline Medial preoptic area & 0.31 \\
\hline Superior colliculus & 0.28 \\
\hline Inferior olive & 0.27 \\
\hline Lateral habenula & 0.26 \\
\hline Periaquaductal gray matter & 0.23 \\
\hline Cortex, occipital & 0.22 \\
\hline Medial septal nucleus & 0.22 \\
\hline Thalamus, posterior nucleus & 0.22 \\
\hline Globus pallidus & 0.17 \\
\hline Cerebellum, molecular layer & 0.15 \\
\hline Corpus callosum & 0.15 \\
\hline Brainstem reticular formation & 0.15 \\
\hline
\end{tabular}

Data are from a representative in situ hybridization experiment quantified as described in Materials and Methods (the average of duplicate measurements).

all. CPE mRNA levels and protein are high in magnocellular paraventricular and supraoptic nuclei (Lynch et al., 1984, 1986, 1989; Hook et al., 1985). By in situ hybridization and GEMSA autoradiography, CPE MRNA and protein are relatively low in the caudate. In the brain stem, the parabrachial nucleus and nucleus of tractus solitarius are enriched in CPE mRNA and protein.

CPE mRNA and protein levels also correspond in adrenal and pituitary tissues. CPE was first isolated from purified chromaffin granules of the adrenal medulla (Fricker and Snyder, 1982, 1983; Fricker, 1988). Immunohistochemistry and GEM- 

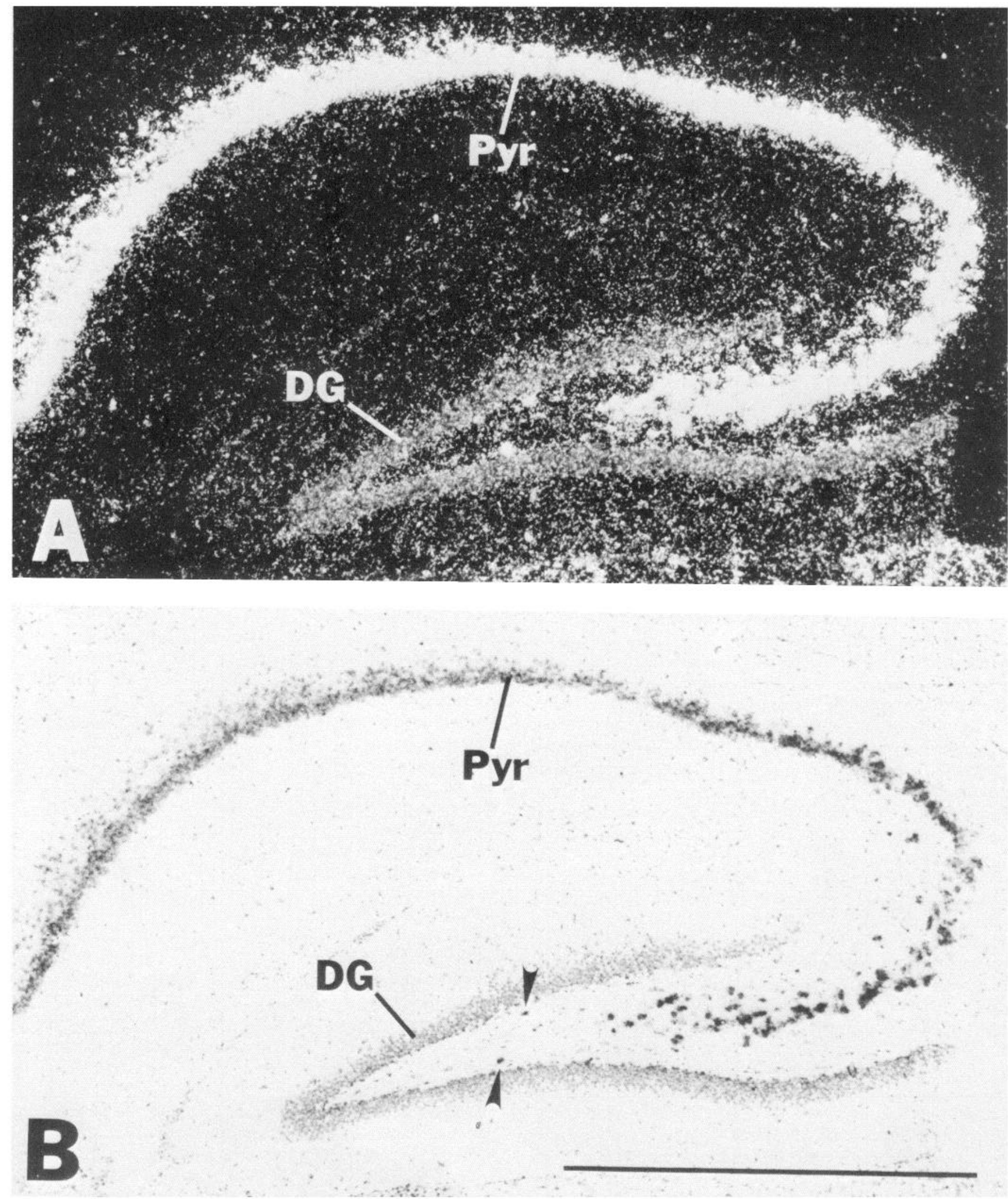

Figure 7. Photomicrograph of CPE antisense labeling of hippocampus. $A, \mathrm{CPE}$ antisense probed hybridization. $B$, Cresyl violet staining to show cell bodies. Arrowheads point to densely labeled cell bodies adjacent to the dentate gyrus. DG, dentate gyrus; Pyr, pyramidal cells in CA3. Scale bar, $1 \mathrm{~mm}$. 
SA autoradiography also reveal high adrenal medullary levels of CPE mRNA and protein (Hook et al., 1985; Strittmatter et al., 1985), in agreement with our mRNA data. CPE can be immunohistochemically localized in adrenal medullary chromaffin cells in culture (Hook et al., 1985). In the pituitary tissues, the higher densities of CPE mRNA in the intermediate than the anterior lobe fit both with GEMSA autoradiography and immunohistochemistry. The lack of labeling in the posterior lobe is consistent with autoradiographic evidence that CPE protein is present in the pathway from the magnocellular hypothalamic nuclei to the posterior pituitary (Strittmatter et al., 1985). CPE protein greatly declines in the posterior pituitary after dehydration, suggesting that it is released by this stimulus, which activates the hypothalamopituitary pathway. Hypothalamic CPE mRNA is unaffected by this treatment, which suggests that, at least in this system, CPE mRNA is constitutively expressed.

In some areas of brain, discrepancies between CPE mRNA and protein levels suggest patterns of CPE neuronal pathways. High densities of CPE protein are present around the granule cell layer of the dentate gyrus, where extremely low levels of CPE mRNA are detected. The CPE protein in this area appears to be in terminals (Lynch et al., 1986) arising from cell bodies in the entorhinal cortex, which contain high levels of CPE mRNA. CPE mRNA is concentrated in medial hebenula neurons, while $\mathrm{CPE}$ protein is high in the interpeduncular nucleus, suggesting that CPE is contained in the habenulo-interpeduncular pathway (fasciculus retroflexus). CPE mRNA is highly concentrated in mitral cells of the olfactory bulb, while CPE protein is densely localized in the most external layers of the piriform cortex, indicating an association of CPE with the mitral cell olfactory efferent pathway.

Areas with levels of CPE mRNA relatively higher than CPE protein include the pontine nuclei, cerebellar cortex, and preoptic area. CPE mRNA levels are greater in the thalamus than in the hypothalamus, while a reverse pattern occurs for CPE protein. The reasons for these discrepancies are not certain; possible explanations include differences in rate of turnover of message or protein, and differences in sensitivities of detection techniques.

We previously observed a close correspondence between the localization of CPE protein and proenkephalin-derived peptides in several brain areas, while in other areas, CPE was expressed in structures that possessed peptides other than the enkephalins or that did not contain any known neuropeptides (Lynch et al., 1984, 1986). A similar pattern emerges for CPE mRNA. Studies of enkephalin- and dynorphin-containing neurons have employed immunohistochemistry (Sar et al., 1978; Uhl et al., 1978, 1979a; Pickel et al., 1980; Finley et al., 1981; Watson et al., 1982) and in situ hybridization (Young et al, 1986a; Morris et al., 1988a, b; Uhl et al., 1988). Regions with neurons enriched in both enkephalins or dynorphin and CPE mRNA include the periglomerula neurons in the olfactory bulb, the lateral septum, the nucleus of the stria terminalis, the anterior olfactory nucleus, the paraventricular and supraoptic nuclei of the hypothalamus, the ventral tegmental nucleus, the dorsal tegmental nucleus, the parabrachial nucleus, the nucleus of the tractus solitarius, and the lateral reticular nucleus. In the paraventricular nucleus of the hypothalamus, CPE mRNA is enriched in both parvocellular and magnocellular portions. Magnocellular neurons contain dynorphin immunoreactivity, while parvocellular neurons contain enkephalin immunoreactivity (Watson et al., 1982).

In some regions, both CPE $\mathrm{mRNA}$ and opioid peptides are enriched, though with a topographic disjunction. For instance, in the amygdala, enkephalin immunoreactivity is highest in the central nucleus, while CPE mRNA is most enriched in the lateral and basolateral nuclei. Several regions have high levels of opioid peptides or their mRNA but little CPE mRNA. For instance, in the dentate granule cells of the hippocampus, CPE mRNA is barely above background, but dynorphin mRNA is enriched (Morris et al., 1988a). A subpopulation of granule cells in the olfactory bulb is strongly immunoreactive for enkephalin (Finley et al., 1981) but does not display CPE mRNA. The corpus striatum has very high levels of preproenkephalin and preprodynorphin mRNA (Young et al., 1986a; Morris et al., 1988a,b; Uhl et al., 1988) and enkephalin immunoreactivity (Pickel et al., 1980) but relatively low levels of CPE mRNA. Moreover, enkephalin expression is highest in the ventral striatum, nucleus accumbens, and ventral pallidum, while CPE mRNA is homogeneously distributed throughout these areas. Other regions relatively enriched in enkephalins but not CPE mRNA include the locus coeruleus, raphe magnus, and spinal trigeminal nucleus. The reasons for these discrepancies in enkephalin and CPE mRNA expression are not certain. Conceivably, the low levels of CPE could be sufficient for opioid peptide processing. In regions like the granule cells of the olfactory bulb and hippocampus, an alternative carboxypeptidase B-like enzyme may process these peptides.

In several areas enriched in CPE, the enzyme may also process peptides other than enkephalins and dynorphin. For instance, hypothalamic magnocellular neurons contain vasopressin and oxytocin (Uhl et al., 1985; Young et al., 1986b), while hypothalamic paraventricular parvocellular neurons contain CRF and neuropeptide Y (Chronwall et al., 1985; Antoni and Linton, 1989). Neurotensin (Uhl et al., 1979b) and atriopeptin (Saper et al., 1985) are concentrated in the nucleus of the tractus solitarius and the parabrachial nucleus, as well as other brain regions. In the hippocampus, somatostatin occurs in the large pyramidal neurons immediately lateral to the dentate gyrus, which are enriched in CPE mRNA. Parathyroid hormone-related peptide is expressed in hippocampal pyramidal neurons (Weir et al., 1989). Substance $\mathbf{P}$ is particularly enriched in neurons in the medial habenula (Cuello and Kanazawa, 1978; Warden and Young, 1988), corresponding to high densities of CPE mRNA.

There remain a number of CPE-enriched brain regions wherein, to our knowledge, no neuropeptide has been localized. These include the pontine nuclei, the red nucleus, and several thalamic subdivisions. If CPE is expressed only in neurons that contain a neuropeptide, then other neuropeptides remain to be discovered. Conversely, as noted above, regions such as the olfactory granule cells and the dentate gyrus granule cell layer contain neuropeptides but little or no CPE, suggesting the existence of other carboxypeptidase B-like processing enzymes.

Note Added in Proof: After this paper was submitted, Birch et al. (1990) presented a distribution of CPE mRNA in rat brain as well.

\section{References}

Antoni FA, Linton EA (1989) Immunocytochemical detection of corticotropin-releasing factor: multiple cross-reactions of a widely used carboxy-terminally directed corticotropin-releasing factor antiserum (code rC70) in rat hypothalamus. Neuroscience 29:167-174.

Birch NP, Rodriguez C, Dixon JE, Mezey E (1990) Distribution of carboxypeptidase $\mathrm{H}$ messenger RNA in rat brain using in situ hy- 
bridization histochemistry: implications for neuropeptide biosynthesis. Mol Brain Res 7:53-59.

Chomczynski P, Sacchi N (1987) Single-step method of RNA isolation by acid guanidinium thiocyanate-phenol-chloroform extraction. Anal Biochem 162:156-159.

Chronwall BM, DiMaggio DA, Massari VJ, Pickel VM, Ruggiero DA, O'Donohue TL (1985) The anatomy of neuropeptide-Y-containing neurons in rat brain. Neuroscience 15:1159-1181.

Cuello AC, Kanazawa I (1978) The distribution of substance P immunoreactive fibers in the rat central nervous system. J Comp Neurol 178:129-156.

Davis LG, Dibner MD, Battey JF (1986) Basic methods in molecular biology. New York: Elsevier.

Finley JCW, Maderdrut JL, Petrusz P (1981) The immunocytochemical localization of enkephalin in the central nervous system of the rat. J Comp Neurol 198:541-565.

Fricker LD (1988) Carboxypeptidase E. Ann Rev Physiol 50:309-321.

Fricker LD, Snyder SH (1982) Enkephalin convertase: purification and characterization of a specific enkephalin-synthesizing carboxypeptidase localized to adrenal chromaffin granules. Proc Natl Acad Sci USA 79:3886-3890.

Fricker LD, Snyder SH (1983) Purification and characterization of enkephalin convertase, an enkephalin-synthesizing carboxypeptidase. J Biol Chem 258:10950-10955.

Fricker LD, Evans CI, Esch FS, Herbert E (1986) Cloning and sequence analysis of cDNA for bovine carboxypeptidase E. Nature 323:461464.

Fricker LD, Adelman JP, Douglas J, Thompson RC, von Strandmann RP, Hutton J (1989) Isolation and sequence analysis of cDNA for rat carboxypeptidase E [EC 3.4.17.10], a neuropeptide processing enzyme. Mol Endocrinol 3:666-673.

Hook VYH, Mezey E, Fricker LD, Pruss RM, Siegel RE, Brownstein MJ (1985) Immunochemical characterization of carboxypeptidase B-like peptide-hormone-processing enzyme. Proc Natl Acad Sci USA 82:4745-4749.

Largent BL, Jones DT, Reed RR, Pearson RCA, Snyder SH (1988) G protein mRNA mapped in rat brain by in situ hybridization. Proc Natl Acad Sci USA 85:2864-2868.

Lynch DR, Snyder SH (1986) Neuropeptides: multiple molecular forms, metabolic pathways, and receptors. Ann Rev Biochem 55:773-799.

Lynch DR, Strittmatter SM, Snyder SH (1984) Enkephalin convertase localization by ${ }^{3} \mathrm{H}$-guanidinoethylmercaptosuccinic acid autoradiography: selective association with enkephalin-containing neurons. Proc Natl Acad Sci USA 81:6543-6547.

Lynch DR, Strittmatter SM, Venable JC, Snyder SH (1986) Enkephalin convertase: localization to specific neuronal pathways. J Neurosci 6:1662-1675.

Lynch DR, Strittmatter SM, Venable JC, Snyder SH (1987) Enkephalin convertase in the gastrointestinal tract and associated organs characterized and localized with ${ }^{3} \mathrm{H}$-guanidinoethylmercaptosuccinic acid. Endocrinology 121:116-126.

Lynch DR, Venable JC, Snyder SH (1988) Enkephalin convertase in the heart: similar disposition to atrial natriuretic factor. Endocrinology 122:2683-2691.

Lynch DR, Braas KM, Hutton JC, Snyder SH (1989) Enkephalin convertase: immunocytochemical localization in the rat central nervous system. J Neurosci

Morris BJ, Feasey KJ, ten Bruggencate G, Herz A, and Hollt V (1988a) Electrical stimulation in vivo increases the expression of proenkephalin mRNA and decreases the expression of prodynorphin mRNA in rat hippocampal granule cells. Proc Natl Acad Sci USA 85:32263230.

Morris BJ, Hollt V, Herz A (1988b) Dopaminergic regulation of striatal proenkephalin mRNA and prodynorphin mRNA: contrasting effects of $D_{1}$ and $D_{2}$ antagonists. Neuroscience 25:525-532.

Pickel VM, Sumal KK, Beckley SC, Miller RJ, Reis DJ (1980) Immunocytochemical localization of enkephalin in the neostriatum of rat brain: a light and electron microscopic study. J Comp Neurol 189: $721-740$.

Ross CA, MacCumber MW, Glatt CE, Snyder SH (1989) Brain phospholipase $\mathrm{C}$ isozymes: differential mRNA localizations by in situ hybridization. Proc Natl Acad Sci USA 86:2923-2927.

Saper CB, Standaert DG, Currie MG, Schwartz D, Geller DM, Needleman $P$ (1985) Atriopeptin-immunoreactive neurons in the brain: presence in cardiovascular regulatory areas. Science 227:1047-1049.

Sar M, Stumpf WE, Miller RJ, Chang K-J, Cuatrecasas P (1978) Immunohistochemical localization of enkephalin in rat brain and spinal cord. J Comp Neurol 182:17-38.

Shinoda H, Marini AM, Cosi C, Schwartz JP (1989) Brain region and gene specificity of neuropeptide gene expression in cultured astrocytes. Science 245:415-417.

Stornetta RL, Hawelu-Johnson CL, Guyenet PG, Lynch KR (1988) Astrocytes synthesize angiotensinogen in brain. Science 242:14441446.

Strittmatter SM, Lynch DR, De Souza EB, Snyder SH (1985) Enkephalin convertase demonstrated in the pituitary and adrenal gland by ${ }^{3} \mathrm{H}$-guanidinoethylmercaptosuccinic acid autoradiography: dehydration decreases neurohypophyseal levels. Endocrinology 117:16671674.

Supattapone S, Fricker LD, Snyder SH (1984) Purification and characterization of a membrane-bound enkephalin-forming carboxypeptidase, "enkephalin convertase." J Neurochem 42:1017-1023.

Uhl GR, Kuhar MJ, Snyder SH (1978) Enkephalin-containing pathway: amygdaloid efferents in the stria terminalis. Brain Res 149:223238 .

Uhl GR, Goodman RR, Kuhar MJ, Childers SR, Snyder SH (1979a) Immunohistochemical mapping of enkephalin containing cell bodies, fibers and nerve terminals in the brain stem of the rat. Brain Res 166 : $75-94$.

Uhl GR, Goodman RR, Snyder SH (1979b) Neurotensin-containing cell bodies, fibers and nerve terminals in the brain stem of the rat: immunohistochemical mapping. Brain Res 167:77-91.

Uhl GR, Zingg HH, Habener JF (1985) Vasopressin mRNA in situ hybridization: localization and regulation studied with oligonucleotide cDNA probes in normal and Brattleboro rat hypothalamus. Proc Natl Acad Sci USA 82:5555-5559.

Uhl GR, Navia B, Douglas J (1988) Differential expression of preproenkephalin and preprodynorphin mRNAs in striatal neurons: high levels of preproenkephalin expression depend on cerebral cortical afferents. J Neurosci 8:4755-4764.

Vilign M-H, Vaysse PJ-J, Zukin RS, Kessler JA (1988) Expression of preproenkephalin mRNA by cultured astrocytes and neurons. Proc Natl Acad Sci USA 85:6551-6555.

Vilign M-H, Das B, Kessler JA, Fricker LD (1989) Cultured astrocytes and neurons synthesize and secrete carboxypeptidase $\mathrm{E}$ [EC 3.4.17.10], a neuropeptide processing enzyme. J Neurochem 53:1487-1493.

Warden MK, Young WS III (1988) Distribution of cells containing mRNAs encoding substance $P$ and neurokinin $B$ in the rat central nervous system. J Comp Neurol 272:90-113.

Watson SJ, Khatchaturian H, Akil H, Coy DH, Goldstein A (1982) Comparison of the distribution of dynorphin systems and enkephalin systems in brain. Science 218:1134-1136.

Weir EC, Brines ML, Ikeda K, Burtis WJ, Broadus AE, Robbins RJ (1989) Parathyroid hormone-related peptide gene is expressed in the mammalian central nervous system. Proc Natl Acad Sci USA 87: 108-112.

Young WS III, Bonner TI, Brann MR (1986a) Mesencephalic dopamine neurons regulate the expression of neuropeptide mRNAs in the rat forebrain. Proc Natl Acad Sci USA 83:9827-9831.

Young WS III, Mezey E, Siegel RE (1986b) Vasopressin and oxytocin mRNA in adrenalectomized and Brattleboro rats: analysis by quantitative in situ hybridization histochemistry. Neurosci Lett 70:198203. 